Research Paper

\title{
The Clinical Effect of Metformin on the Survival of Lung Cancer Patients with Diabetes: A Comprehensive Systematic Review and Meta-analysis of Retrospective Studies
}

\author{
Xun $\mathrm{Cao}^{1 *}$, Zhe-Sheng Wen ${ }^{1,2^{*}}$, Xu-Dong Wang ${ }^{1}$, Yong Li ${ }^{1}$, Kui-Yuan Liu ${ }^{1,2}$, Xin Wang ${ }^{1,2} \bowtie$ \\ 1. Sun Yat-Sen University Cancer Center, State Key Laboratory of Oncology in South China, Collaborative Innovation Center of Cancer Medicine, Guangzhou, \\ Guangdong, China; \\ 2. Department of Thoracic Oncology, Sun Yat-Sen University Cancer Center, Guangzhou, Guangdong, China. \\ *Xun Cao and Zhe-Sheng Wen have contributed equally to this work.
}

$\triangle$ Corresponding author: Dr. Xin Wang, MD, Department of Thoracic Oncology, Sun Yat-Sen University Cancer Center, State Key Laboratory of Oncology in South China, Collaborative Innovation Center of Cancer Medicine, No. 651 Dong-Feng Road East, Guangzhou, Guangdong 510060, China. E-mail: caoxun@sysucc.org.cn (Xin Wang)

(c) Ivyspring International Publisher. This is an open access article distributed under the terms of the Creative Commons Attribution (CC BY-NC) license (https://creativecommons.org/licenses/by-nc/4.0/). See http://ivyspring.com/terms for full terms and conditions.

Received: 2017.02.21; Accepted: 2017.05.30; Published: 2017.08.02

\begin{abstract}
Preclinical investigations have revealed an anti-cancer effect of metformin. Several studies of metformin treatment have demonstrated the improved clinical outcomes of lung cancer patients with diabetes; however, the results have been inconsistent among studies. Our systematic review and meta-analysis aimed to summarize the up-to-date effects of metformin on diabetic lung cancer patients.

A systematic search was performed for studies published. Then, these studies were evaluated for inclusion, and relevant data was extracted. The summary risk estimates for the associations of metformin treatment with overall survival (OS) and progression-free survival (PFS) were analyzed using random/fixed-effects models. Analyses stratified by histological type were also conducted. Based on the 10 studies included in our analysis, metformin treatment was found to significantly improve survival, corresponding to reductions of $23 \%$ and $47 \%$ in OS [hazard ratio $(\mathrm{HR})=0.77,95 \%$ confidence interval $(95 \% \mathrm{Cl})=0.66-0.9, p=0.001]$ and PFS $(\mathrm{HR}=0.53,95 \% \mathrm{Cl}=0.41-0.68, p<0.001)$, respectively. In addition, significant improvements in the OS for non-small cell lung cancer (NSCLC) (HR=0.77, $95 \% \mathrm{Cl}=0.71-0.84, p=0.002)$ and small cell lung cancer $(\mathrm{SCLC})(\mathrm{HR}=0.52,95 \% \mathrm{Cl}=0.29-0.91, p=0.022)$ were observed in association with metformin treatment in analysis stratified by histological type. This stratified analysis also revealed a significant improvement in PFS for both NSCLC (HR $=0.53$, $95 \% \mathrm{Cl}=0.39-0.71, p<0.001)$ and SCLC $(\mathrm{HR}=0.54,95 \% \mathrm{Cl}=0.34-0.84, p=0.007)$. We found that metformin treatment significantly improved the OS and PFS of diabetic lung cancer patients, and our findings suggest that metformin might be an effective treatment option for diabetic patients with lung cancer.
\end{abstract}

Key words: Lung cancer; Diabetes; Metformin; Survival; Meta-analysis.

\section{Introduction}

Diabetes mellitus is the most common metabolic disease, and it is caused by either a deficiency in pancreatic insulin production or resistance of insulin-responsive cells to the insulin produced [1]. Clinically, approximately $20 \%$ of patients with cancer have concurrent diabetes, which could be due to the biological links between these two diseases [2]. Previous experimental studies have suggested that an increased neoplastic proliferation rate and an increased risk of tumor progression or metastasis occur in cancer patients with concurrent diabetes mellitus, which could be due to the effects of 
hyperinsulinemia, hyperglycemia, and inflammatory cytokines [3-6].

There is increasing interest in investigating the potential use of already-approved medications as anti-cancer agents [7-9]. Metformin is a glucose-lowering agent that improves insulin sensitivity and lowers the circulating insulin level in patients with type II diabetes mellitus [10]. It is the most commonly prescribed oral antidiabetic drug, and it is recommended as the first-line therapy because it is relatively inexpensive, safe, effective, and well-tolerated [11]. Over the past several years, some studies have investigated the effects of metformin treatment on cancer. Basic biochemical studies have provided a better understanding of the mechanisms underlying the anti-tumor activity of metformin and its potential to modulate molecular pathways involved in cancer cell signaling and metabolism [12-14].

Lung cancer is the leading cause of cancer-related death worldwide [15]. Despite advances in surgical and radiotherapy techniques and the availability of new chemotherapeutic agents, the outcomes of patients with lung cancer are still not satisfactory [16]. Thus, there is a need to develop new strategies to improve the efficacies of the current treatment modalities. Several published studies have reported that metformin treatment improves the survival of lung cancer patients with diabetes [17-23]; however, the results of other studies have been inconsistent [24-26]. Therefore, we conducted the present systematic review and meta-analysis to provide reliable and up-to-date evidence on the effects of metformin treatment on lung cancer patient survival and to further evaluate this association according to histologic subgroups.

\section{Material and Methods}

\section{Study selection and data extraction}

The following computerized bibliographic databases were searched for relevant articles: PubMed (PubMed Central-National Center for Biotechnology Information, PMC-NCBI), EMBASE, and ISI Web of Science (Science Citation Index Expanded). The following search terms were used: "lung cancer", "diabetes mellitus or diabetes", "metformin", "mortality", "survival", and "prognosis". A manual search was performed for references cited in the selected articles and reviews. Articles for which the abstract or full text was not available in English were excluded after review. The search included studies up to April of 2017.
Studies of patients with concurrent lung cancer and diabetes that evaluated the effect of metformin treatment on survival were included. All included studies defined glucose-lowering drug exposure (metformin or non-metformin) in subgroups and further compared metformin-treated patients with non-metformin-treated patients. The criteria for excluding studies in the present analysis were as follows: (1) failure to provide an adjusted hazard ratio (HR) with an estimated 95\% confidence interval (95\% $\mathrm{CI})$; (2) inclusion of non-diabetic patients in the non-metformin group; and (3) inclusion of patients with type I diabetes mellitus. Two investigators (X. C. and Z. S. W.) independently extracted the following data from each included study: the first author, study region, publication year, study period, study design, tumor histology, tumor stage, length of follow-up, glucose-lowering drug treatment used (metformin or non-metformin), adjusted covariates, and adjusted estimates. A third investigator (X. W.) reviewed the extracted data. Any discrepancies in the course of article selection and data extraction were resolved by group discussion.

\section{Statistical analysis}

Adjusted Cox proportional HRs were used for quantitative analysis, and combined HRs for overall survival (OS) and progression-free survival (PFS) were calculated for the patients with lung cancer and diabetes treated (or not) with metformin. Additionally, subgroup analyses according to histological type were performed. Survival curves were estimated for metformin and non-metformin groups according to the method by the Early Breast Cancer Trialists' Collaborative Group [27]. Heterogeneity across studies was estimated using the $\chi^{2}$ test and the $I^{2}$ statistic, and the proper effect models were chosen accordingly. Statistically significant heterogeneity was defined as an $I^{2}>50 \%$ or a $\chi^{2}$ $p$-value $<0.1[28]$. If significant heterogeneity was observed, then the summary estimation was based on a random-effects model, according to the DerSimonian and Laird method [29]. If significant heterogeneity was not observed, then the summary estimation was based on a fixed-effects model. Furthermore, potential obvious heterogeneity was explored through sensitivity analysis. Begg's and Egger's tests were used to detect potential publication bias. All statistical analyses were conducted using STATA software version 14.0 (StataCorp, College Station, TX, USA). A two-sided $p$-value of $<0.05$ was considered significant all analyses except for the heterogeneity tests. 


\section{Results}

\section{Meta-analysis database}

Figure 1 shows the flow chart for study selection. Initially, 168 articles were retrieved from the computerized bibliographic databases, of which 120 were duplicates. After title screening, 15 studies were recommended for abstract review. Studies that did not report survival information and those that were laboratory investigations, case reports, commentaries, reviews or meta-analyses were excluded from our analysis. Of the abstracts reviewed [30], 14 of the corresponding studies were eligible for further full-text review. We further excluded studies that (1) did not provide statistical data on OS or PFS in the full-text [31], (2) did not provided an adjusted HR with an estimated $95 \% \mathrm{CI}[32,33]$, or (3) included non-diabetic lung cancer patients in the non-metformin treatment group [34]. After the full-text review, a total of 10 studies were ultimately included [17-26], which consisted of 10 studies that reported OS [17-26], 5 that reported PFS [18-20, 24, $25]$, and 5 that presented both measures [18-20, 24, 25]. Two studies included all histological types [21, 26], 6 reported on non-small cell lung cancer (NSCLC) [17, $18,22,24,25]$, and 2 reported on small cell lung cancer (SCLC) [19, 20]. Among the 10 studies, which consisted of 4,052 patients, 1,719 patients received metformin alone or in combination with another glucose-lowering regimen, and the remaining 2,333 received non-metformin therapy. The detailed characteristics of the included studies are shown in Table 1.

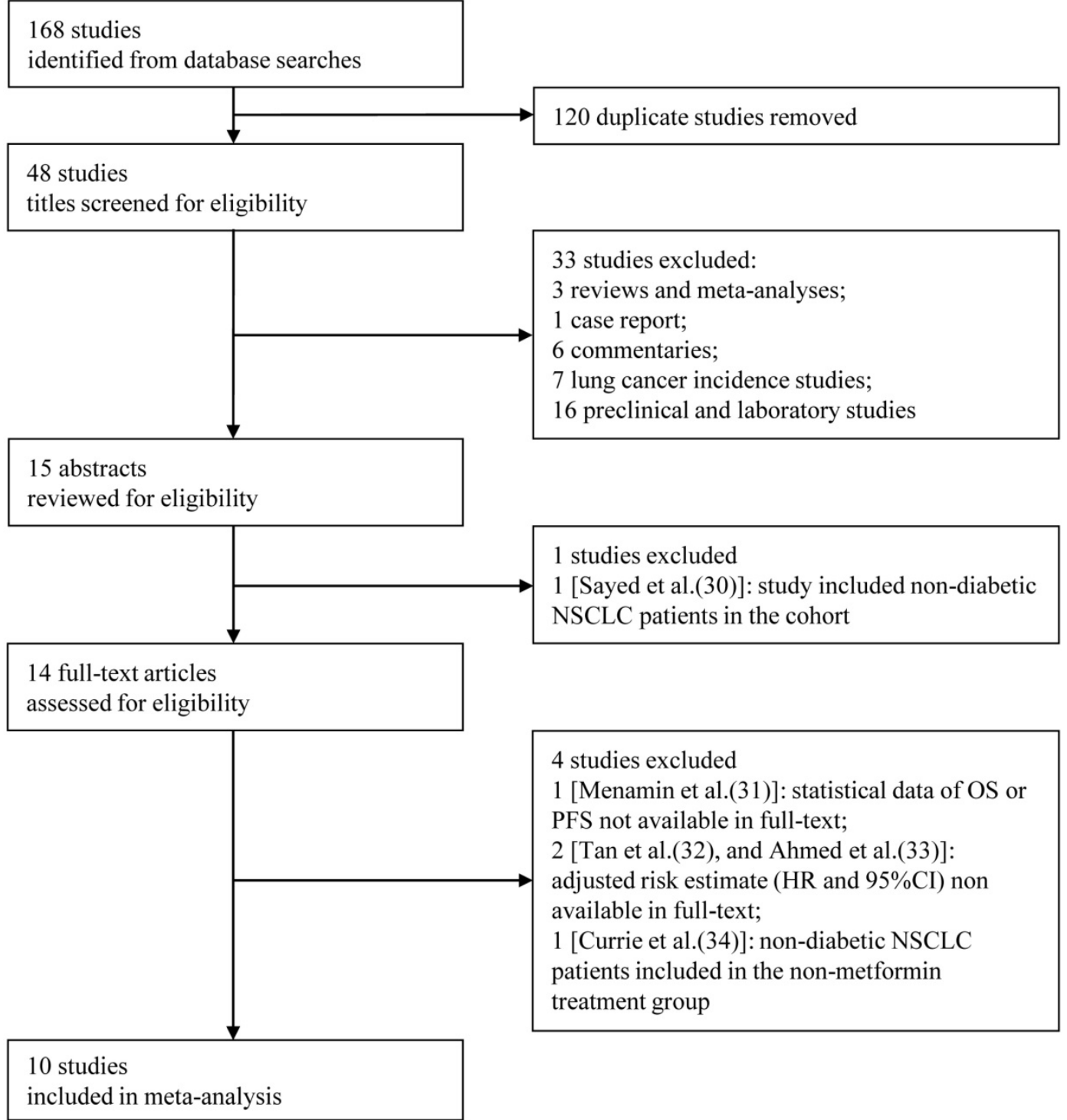

Figure 1. Flow diagram showing the inclusion and exclusion criteria for the studies. 
Table 1. Summary characteristics of included studies.

\begin{tabular}{|c|c|c|c|c|c|c|c|c|c|c|}
\hline $\begin{array}{l}\text { Study } \\
\text { (Country) }\end{array}$ & $\begin{array}{l}\text { Year } \\
\text { (Study } \\
\text { period) }\end{array}$ & $\begin{array}{l}\text { Study } \\
\text { Design }\end{array}$ & Histology & Stage & $\begin{array}{l}\text { Follow-up } \\
\text { Time } \\
\text { (median) }\end{array}$ & Treatment & $\begin{array}{l}\text { Anti-diabetic } \\
\text { Treatment }\end{array}$ & Adjustment Variables & OS & PFS \\
\hline $\begin{array}{l}\text { Lin et al. [23] } \\
\text { (USA) }\end{array}$ & $\begin{array}{l}2017 \\
(2002-2007)\end{array}$ & $\begin{array}{l}\text { Retrospective } \\
\text { cohort study }\end{array}$ & NSCLC & I-IV & $\begin{array}{l}14.6 \\
\text { months }\end{array}$ & $\begin{array}{l}\text { Surgery } \\
\text { Chemotherapy } \\
\text { Radiotherapy }\end{array}$ & $\begin{array}{l}\text { Met: } 259 \\
\text { Other: } 377\end{array}$ & $\begin{array}{l}\text { Age, sex, race, tobacco use, } \\
\text { comorbidities, stage, } \\
\text { histology, treatments, } \\
\text { insulin/insulin } \\
\text { secretogogue/aspirin use }\end{array}$ & $\mathrm{Y}$ & $\mathrm{N}$ \\
\hline $\begin{array}{l}\text { Arrieta et al. } \\
\text { [22] (Mexico) }\end{array}$ & $\begin{array}{l}2016 \\
(2008-2014)\end{array}$ & $\begin{array}{l}\text { Retrospective } \\
\text { cohort study }\end{array}$ & NSCLC & II-IV & $\begin{array}{l}10.8 \\
\text { months }\end{array}$ & No reported & $\begin{array}{l}\text { Met: } 111 \\
\text { Other: } 75\end{array}$ & $\begin{array}{l}\text { Gender, smoking, stage, } \\
\text { glycemic control }\end{array}$ & $\mathrm{Y}$ & $\mathrm{N}$ \\
\hline $\begin{array}{l}\text { Medairos et al. } \\
\text { [24] (USA) }\end{array}$ & $\begin{array}{l}2016 \\
(2004-2013)\end{array}$ & $\begin{array}{l}\text { Retrospective } \\
\text { cohort study }\end{array}$ & NSCLC & I-II & $\begin{array}{l}19.5 \\
\text { months }\end{array}$ & $\begin{array}{l}\text { Surgery } \\
\text { Chemotherapy }\end{array}$ & $\begin{array}{l}\text { Met: } 81 \\
\text { Other: } 57\end{array}$ & $\begin{array}{l}\text { Age, gender, } \mathrm{T} \text { stage, } \mathrm{N} \\
\text { stage }\end{array}$ & Y & $\mathrm{Y}$ \\
\hline $\begin{array}{l}\text { Wink et al. [25] } \\
\text { (Netherlands) }\end{array}$ & $\begin{array}{l}2016 \\
(2008-2013)\end{array}$ & $\begin{array}{l}\text { Retrospective } \\
\text { cohort study }\end{array}$ & NSCLC & III-IV & 30 months & $\begin{array}{l}\text { Concurrent } \\
\text { chemoradiotherapy }\end{array}$ & $\begin{array}{l}\text { Met: } 59 \\
\text { Other: } 623\end{array}$ & Age, gender, stage, PS & Y & $\mathrm{Y}$ \\
\hline $\begin{array}{l}\text { Lin et al. [17] } \\
\text { (USA) }\end{array}$ & $\begin{array}{l}2015 \\
(2007-2009)\end{array}$ & $\begin{array}{l}\text { Retrospective } \\
\text { population-based } \\
\text { study }\end{array}$ & NSCLC & IV & $\begin{array}{l}\text { No } \\
\text { reported }\end{array}$ & $\begin{array}{l}\text { Chemotherapy } \\
\text { TKI } \\
\text { Other }\end{array}$ & $\begin{array}{l}\text { Met: } 458 \\
\text { Other: } 292\end{array}$ & $\begin{array}{l}\text { Sociodemographic factors, } \\
\text { comorbidities, PS, diabetic } \\
\text { medications, diabetic } \\
\text { severity score, PET use, } \\
\text { tumor characteristics, } \\
\text { chemotherapy }\end{array}$ & Y & $\mathrm{N}$ \\
\hline $\begin{array}{l}\text { Chen et al. [18] } \\
\text { (China) }\end{array}$ & $\begin{array}{l}2015 \\
(2006-2014)\end{array}$ & $\begin{array}{l}\text { Retrospective } \\
\text { cohort study }\end{array}$ & NSCLC & III-IV & $\begin{array}{l}\text { No } \\
\text { reported }\end{array}$ & TKI & $\begin{array}{l}\text { Met: } 44 \\
\text { Other: } 46\end{array}$ & No reported & $\mathrm{Y}$ & $\mathrm{Y}$ \\
\hline $\begin{array}{l}\text { Xu et al. [20] } \\
\text { (China) }\end{array}$ & $\begin{array}{l}2015 \\
(2000-2010)\end{array}$ & $\begin{array}{l}\text { Retrospective } \\
\text { cohort study }\end{array}$ & SCLC & $\begin{array}{l}\text { Limited and } \\
\text { extensive }\end{array}$ & 65 months & $\begin{array}{l}\text { Chemotherapy } \\
\text { surgery }\end{array}$ & $\begin{array}{l}\text { Met: } 36 \\
\text { Other: } 43\end{array}$ & $\begin{array}{l}\text { Age, gender, NSE, LDH, } \\
\text { tobacco use, stage, PS }\end{array}$ & $\mathrm{Y}$ & $\mathrm{Y}$ \\
\hline $\begin{array}{l}\text { Kong et al. [19] } \\
\text { (China) }\end{array}$ & $\begin{array}{l}2015 \\
(2001-2011)\end{array}$ & $\begin{array}{l}\text { Retrospective } \\
\text { cohort study }\end{array}$ & SCLC & $\begin{array}{l}\text { Limited and } \\
\text { extensive }\end{array}$ & 68 months & $\begin{array}{l}\text { Chemotherapy } \\
\text { surgery }\end{array}$ & $\begin{array}{l}\text { Met: } 120 \\
\text { Other: } 139\end{array}$ & $\begin{array}{l}\text { Age, gender, NSE, LDH, } \\
\text { smoking, stage, PS }\end{array}$ & Y & $\mathrm{Y}$ \\
\hline $\begin{array}{l}\text { Xu et al. [21] } \\
\text { (USA) }\end{array}$ & $\begin{array}{l}2015 \\
(1995-2010)\end{array}$ & $\begin{array}{l}\text { Retrospective } \\
\text { cohort study }\end{array}$ & All & $\begin{array}{l}\text { No } \\
\text { reported }\end{array}$ & $\begin{array}{l}\text { No } \\
\text { reported }\end{array}$ & No reported & $\begin{array}{l}\text { Met: } 155 / 212 \\
\text { Insulin: } 19 / 88 \\
\text { Other: } 72 / 179\end{array}$ & $\begin{array}{l}\text { Age, sex, race, BMI, tobacco } \\
\text { use, insulin use, Charlson } \\
\text { Index }\end{array}$ & Y & $\mathrm{N}$ \\
\hline $\begin{array}{l}\text { Mazzone et al. } \\
\text { [26] (USA) }\end{array}$ & $\begin{array}{l}2012 \\
(1978-2010)\end{array}$ & $\begin{array}{l}\text { Retrospective } \\
\text { case-control study }\end{array}$ & All & No reported & $\begin{array}{l}\text { No } \\
\text { reported }\end{array}$ & No reported & $\begin{array}{l}\text { Met: } 184 \\
\text { Other: } 323\end{array}$ & Age, stage & $\mathrm{Y}$ & $\mathrm{N}$ \\
\hline
\end{tabular}

Abbreviation: OS, overall survival; PFS, progression-free survival; NSCLC, non-small cell lung cancer; SCLC, small cell lung cancer; met, metformin; TKI, tyrosine kinase inhibitor; PS, performance status; PET, positron emission tomography; NSE, neuronal specific enolase; LDH, lactate dehydrogenase; BMI, body mass index.

\section{Effect of metformin on survival of all diabetic lung cancer patients}

Ten studies were available for inclusion in OS analysis based on metformin treatment of diabetic patients with lung cancer [17-26], of which 7 reported a significant improvement in OS [17-23], 3 found no correlation [21, 24, 25], and 1 reported a decrease in OS [26]. Our meta-analysis revealed that the diabetic lung cancer patients treated with metformin displayed a significant improvement in OS compared with those who did not receive metformin (random-effects model, pooled HR=0.77, $95 \% \mathrm{CI}=0.66-0.9, p=0.001)$. Significant heterogeneity was observed in our analysis $\left(I^{2}=63.3 \%, p=0.001\right)$. For the heterogeneity, sensitivity analysis was performed. The details of analysis are summarized in Figure 2(A-B). The estimated survival curve is shown in Figure 4(A). The results of Begg's $(p=0.951)$ and Egger's $(p=0.524)$ tests suggested no evidence of publication bias. Notably, in the study by Xu et al. [21], among patients from the Mayo Clinic health records system, metformin treatment was associated with a significant improvement in OS relative to other oral hypoglycemic medications and insulin; however, no benefit of metformin was observed in patients from the Vanderbilt electronic health records system.
Data on PFS were available for 5 studies, all of which reported a significant improvement in the PFS of metformin-treated patients [18-20, 24, 25]. Meta-analysis demonstrated that metformin treatment was associated with increased PFS compared with non-metformin treatment, and this difference was statistically significant (fixed-effects model, pooled $\mathrm{HR}=0.53$, 95\% $\mathrm{CI}=0.41-0.68, p<0.001$; heterogeneity, $I^{2}=0 \%, p=0.829$ ) (Figure 2C). The estimated survival curve is shown in Figure 4(B). No evidence of publication bias was detected (Begg's test, $p=0.806$; Egger's test, $p=0.978$ ).

\section{Effect of metformin on survival of diabetic NSCLC patients}

Six studies on NSCLC provided data on OS [17, 18, 22-25]. Four studies reported that the OS of metformin-treated patients was significantly better than that of non-metformin-treated patients [17, 18, 22, 23], whereas the other study did not find a significant association [24, 25]. The pooled HR was 0.77 (95\% CI=0.71-0.84 by fixed-effects model, $p=0.002)$ [Figure 3(A)]. The estimated survival curve is shown in Figure $4(\mathrm{C})$. No significant evidence of heterogeneity was observed in these studies $(I 2=24.1 \%, p=0.253)$, and no evidence of publication bias was detected (Begg's test, $p=0.707$; Egger's test, $p=0.352$ ). 
(A) Study

Lin et al. [23]

Arrieta et al. [22]

Medairos et al. [24]

Wink et al. [25]

Lin et al. [17]

Chen et al. [18]

$\mathrm{Xu}$ et al. [20]

Kong et al. [19]

$\mathrm{Xu}$ et al. [21] ${ }^{\mathrm{a}}$

Xu et al. [21] b

Xu et al. [21] ${ }^{\mathrm{c}}$

Xu et al. [21] ${ }^{\mathrm{d}}$

Mazzone et al. [26]

Heterogeneity: $P^{R}=63.3 \%, \mathrm{P}=0.001$

Test for overall effect: $\mathrm{Z}=3.22, \mathrm{P}=0.001$
Hazard Ratio (95\%CI)

$0.76(0.65,0.88)$

$0.57(0.36,0.90)$

$0.78(0.22,2.69)$

$0.86(0.57,1.28)$

$0.80(0.71,0.89)$

$0.44(0.26,0.76)$

$0.55(0.20,0.98)$

$0.49(0.18,0.89)$

$0.93(0.48,1.80)$

$0.90(0.64,1.28)$

$0.59(0.40,0.85)$

$0.76(0.58,0.99)$

$1.47(1.12,1.92)$

$0.77(0.66,0.90)$

(B) Meta-analysis estimates

Lin et al. [23]

Arrieta et al. [22]

Medairos et al. [24]

Wink et al. [25]

Lin et al. [17]

Chen et al. [18]

$\mathrm{Xu}$ et al. [20]

Kong et al. [19]

Xu et al. [21] a

$\mathrm{Xu}$ et al. [21] b

$\mathrm{Xu}$ et al. [21] ${ }^{\mathrm{c}}$

$\mathrm{Xu}$ et al. [21] d

Mazzone et al. [26]

Favors metformin

Favors non-metformin
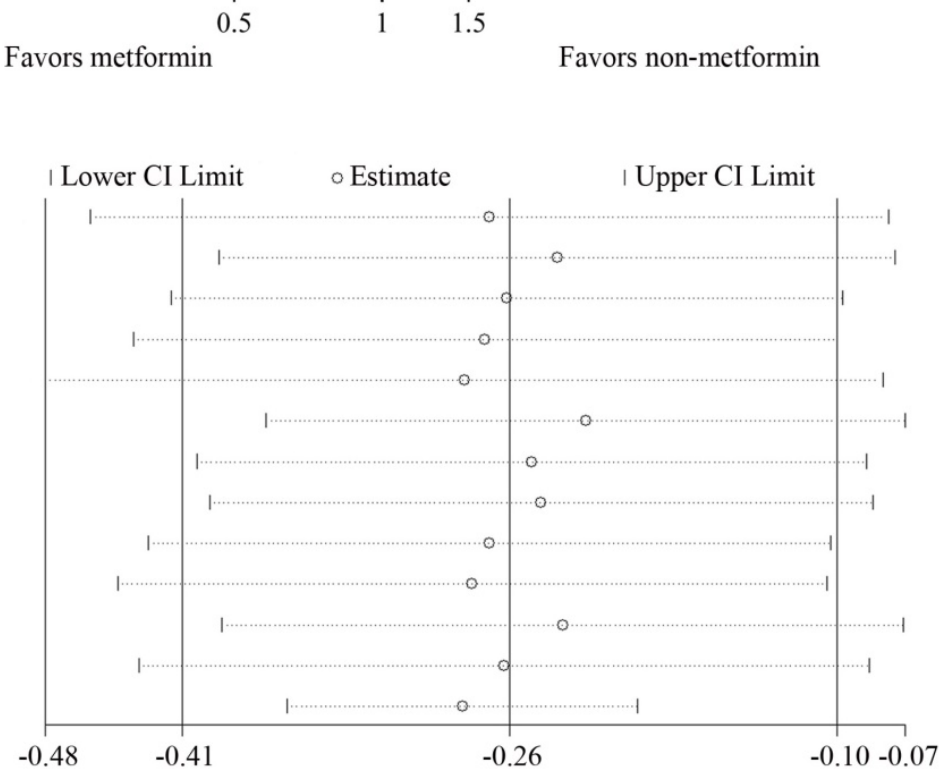

(C) Study

Hazard Ratio $(95 \% \mathrm{CI})$

Medairos et al. [24]

Wink et al. [25]

Chen et al. [18]

$\mathrm{Xu}$ et al. [20]

Kong et al. [19]

Heterogeneity: $P=0 \%, \mathrm{P}=0.829$

Test for overall effect: $Z=5.06, \mathrm{P}<0.001$

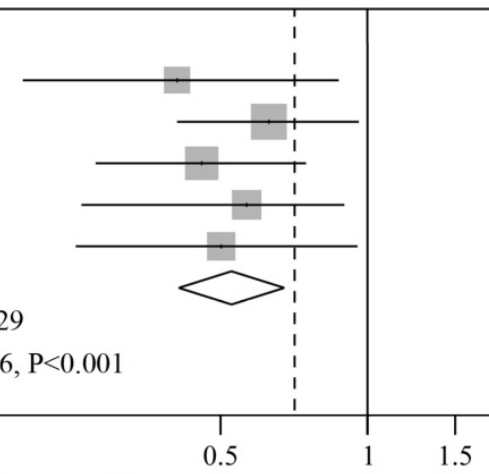

Favors metformin

Favors non-metformin

$0.41(0.20,0.87)$

$0.63(0.41,0.96)$

$0.46(0.28,0.75)$

$0.57(0.26,0.90)$

$0.50(0.25,0.95)$

$0.53(0.41,0.68)$

Figure 2. Survival of patients with lung cancer and diabetes who received metformin treatment vs. non-metformin treatment. (A) Forest plot of effects of metformin vs. non-metformin treatment on the overall survival of all diabetic patients with lung cancer; (B) Forest plot of sensitivity analysis for the heterogeneity of studies included in Figure 2(A); (C) Forest plot of effects of metformin vs. non-metformin treatment on the progression-free survival of all diabetic patients with lung cancer. Results from the Vanderbilt electronic health records system: a metformin vs. insulin, b metformin vs. other medications; results from the Mayo Clinic electronic health records system: c metformin vs. insulin, d metformin vs. other medications. 
(A) Study

Hazard Ratio $(95 \% \mathrm{CI})$

Lin et al. [23]

Arrieta et al. [22]

Medairos et al. [24]

Wink et al. [25]

Lin et al. [17]

Chen et al. [18]

Heterogeneity: $P=24.1 \%, \mathrm{P}=0.253$

Test for overall effect: $Z=6.04, \mathrm{P}=0.002$

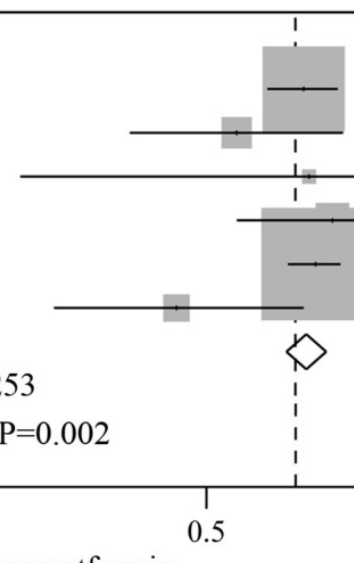

Favor metformin
Favor non-metformin
$0.76(0.65,0.88)$

$0.57(0.36,0.90)$

$0.78(0.22,2.69)$

$0.86(0.57,1.28)$

$0.80(0.71,0.89)$

$0.44(0.26,0.76)$

$0.77(0.71,0.84)$

(B) Study

Hazard Ratio (95\%CI)

Medairos et al. [24]

Wink et al. [25]

Chen et al. [18]

Heterogeneity: $P^{2}=0 \%, \mathrm{P}=0.494$

Test for overall effect: $Z=4.27, \mathrm{P}<0.001$

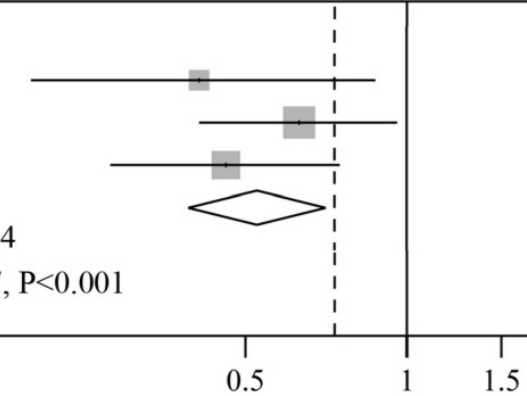

Favor metformin

Favor non-metformin

$0.41(0.20,0.87)$

$0.63(0.41,0.96)$

$0.46(0.28,0.75)$

$0.53(0.39,0.71)$

(C) Study

Hazard Ratio (95\%CI)

Xu et al. [20]

Kong et al. [19]

Heterogeneity: $P^{2}=0 \%, \mathrm{P}=0.83$

Test for overall effect: $Z=2.29, \mathrm{P}=0.022$

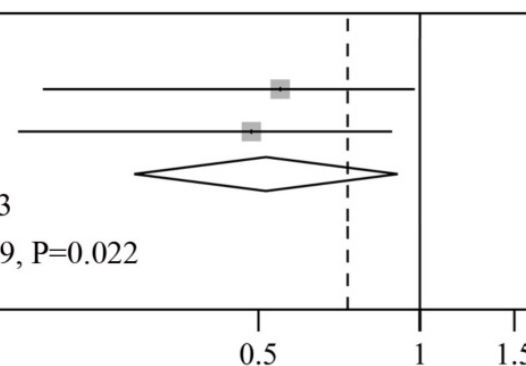

Favor metformin
Favor non-metformin

$0.55(0.20,0.98)$

$0.49(0.18,0.89)$

$0.52(0.29,0.91)$

(D) Study

Hazard Ratio (95\%CI)

Xu et al. [20]

Kong et al. [19]

Heterogeneity: $P^{2}=0 \%, \mathrm{P}=0.795$

Test for overall effect: $Z=2.71, \mathrm{P}=0.007$

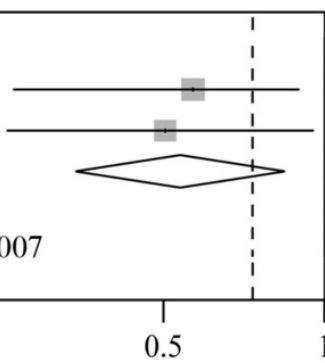

Favor metformin
Favor non-metformin

Figure 3. Subgroup analysis according to histological type of the survival of patients with lung cancer and diabetes who received metformin vs. non-metformin treatment. (A) Forest plot of effects of metformin vs. non-metformin treatment on the overall survival (OS) of diabetic patients with non-small cell lung cancer (NSCLC); (B) Forest plot of effects of metformin vs. non-metformin treatment on the progression-free survival (PFS) of diabetic patients with NSCLC; (C) Forest plot of effects of metformin vs. non-metformin treatment on the OS of diabetic patients with small cell lung cancer (SCLC); (D) Forest plot of effects of metformin vs. non-metformin treatment on the PFS of diabetic patients with SCLC. 

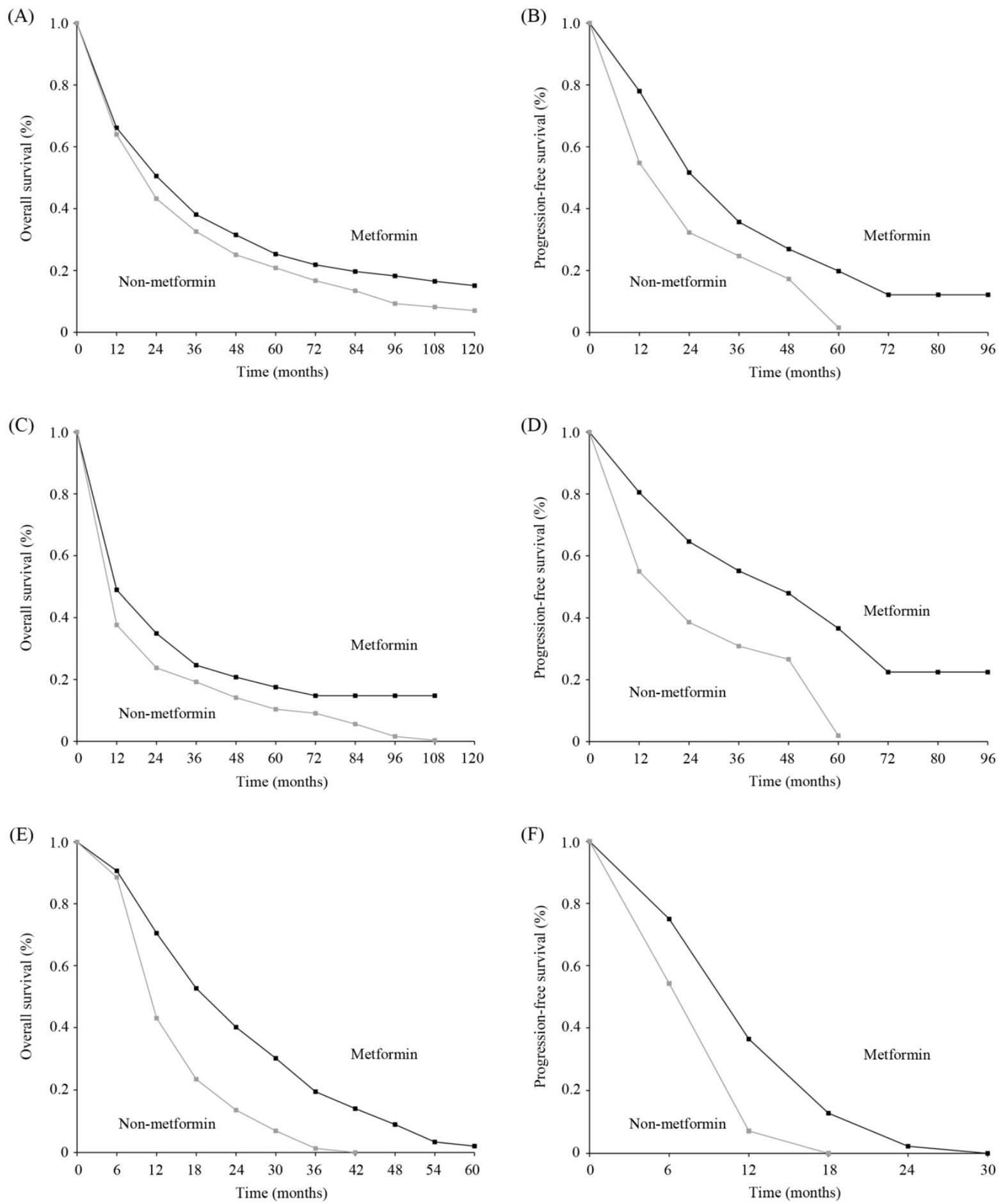

Figure 4. Estimated survival curves. (A) Overall survival (OS) curves for all diabetic patients with lung cancer; (B) Progression-free survival (PFS) curves for all diabetic patients with lung cancer; (C) OS curves for the diabetic patients with non-small cell lung cancer (NSCLC); (D) PFS curves for the diabetic patients with NSCLC; (E) OS curves for the diabetic patients with small cell lung cancer (SCLC); (F) PFS curves for the diabetic patients with SCLC.

PFS data for diabetic NSCLC patients were reported in 3 studies [18, 24, 25], all of which reported that the PFS of metformin-treated patients was significantly better than that of non-metformin-treated patients. Our analysis revealed that PFS was significantly prolonged in metformin-treated patients (pooled $\mathrm{HR}=0.53$,
95\% CI $=0.39-0.71, \quad p<0.001) \quad$ [Figure 3(B)]. The estimated survival curve is shown in Figure 4(D). This analysis was based on a fixed-effects model because no evidence of heterogeneity was observed among the included studies $\left(I^{2}=0 \%, p=0.494\right)$, and no evidence of publication bias was detected (Begg's test, $p=0.602$; Egger's test, $p=0.884)$. 


\section{Effect of metformin on survival of diabetic SCLC patients}

Two studies on SCLC in diabetic patients provided OS data, all of which reported a significant improvement in the OS of metformin-treated patients $[19,20]$. The pooled HR was $0.52(95 \% \mathrm{CI}=0.29-0.91$ by fixed-effects model, $p=0.022$ ) [Figure 3(C)]. The estimated survival curve is shown in Figure 4(E). No evidence of heterogeneity was observed among the data $\left(I^{2}=0 \%, p=0.83\right)$, and the Begg's test results suggested no evidence of publication bias $(p=0.317)$.

Data on PFS were available for 2 studies [19, 20], all of which reported that the PFS of metformin-treated patients was significantly better than that of non-metformin-treated patients. Our analysis revealed that metformin treatment yielded a significant improvement in PFS compared with non-metformin treatment (fixed-effects model, pooled $\mathrm{HR}=0.54,95 \% \mathrm{CI}=0.34-0.84, p=0.007$; heterogeneity, $\left.I^{2}=0 \%, p=0.795\right)$ [Figure 3(D)]. The estimated survival curve is shown in Figure 4(F). Publication bias was not observed based on Begg's test $(p=0.317)$.

\section{Discussion}

Since 2010, studies of the effects of metformin on cancer survival have increased considerably. Several previous studies have suggested that metformin might modulate the prognosis of diabetic cancer patients, as patients treated with metformin showed significantly better survival than those who received another anti-diabetic medication. Lin et al. have reported that metformin treatment improves the survival of diabetic patients with stage IV lung cancer [17], in line with the results of 5 retrospective cohort studies [18-20, 22, 23]. Nevertheless, another 2 recent studies have yielded negative results. Medairos et al. have found no evidence of an association between metformin use and OS in a cohort of 215 patients with diabetes and lung cancer [24]. In addition, Wink et al. have reported no difference in OS between metformin-treated and non-metformin-treated diabetic lung cancer patients receiving concurrent chemoradiotherapy [25]. Thus, it is important to perform pooled analysis to evaluate the effects of metformin treatment on the survival of diabetic patients with lung cancer to obtain more information for patient management.

Based on data from 10 studies, we demonstrated reductions of $21 \%$ and $47 \%$ in OS and PFS, respectively, in patients with lung cancer and diabetes who used metformin. In analysis stratified by histological type, we revealed that metformin treatment yielded a significant improvement in OS compared with other anti-diabetic medications in both NSCLC and SCLC. Metformin use was also associated with a significant improvement in PFS for both NSCLC and SCLC.

Notably, the study conducted by Mazzone et al. is the only one showing the reduced survival of diabetic lung cancer patients who received metformin [26]. Conversely, 6 other included studies provided evidence of a positive effect of metformin treatment on survival [17-20, 22, 23]. There are several possible reasons for these discrepant findings among studies. First, differences in adjustments for patient characteristics could have led to bias in the results among studies. Second, Mazzone et al. included diabetic lung cancer patients of all stages, and they did not control for differences in lung cancer treatments in their analyses. Moreover, the unknown and potential interactions between metformin and the different histological lung cancer subtypes could have influenced the clinical outcomes of these populations; these possibilities merit additional research.

In the present meta-analysis, the findings of Medairos et al. and Wink et al. suggested that the treatment of diabetic NSCLC patients with metformin was associated with improved PFS but that it had no effect on OS [24, 25]. To the best of our knowledge, preclinical studies have demonstrated that metformin may act by preventing progression; thus, simply comparing patients treated (or not) with metformin may not capture its effects. The examination of time-dependent cumulative variables for metformin exposure is important to further evaluate whether it influences the clinical outcomes of patients with cancer and diabetes [35]. Margel et al. have demonstrated that the cumulative duration of metformin treatment is associated with a significant improvement in the survival of diabetic prostate cancer patients [36]. In addition, Vissers et al. and Peeters et al. both have reported an improvement in the cancer-specific survival of diabetic breast cancer patients with cumulative metformin exposure [37, 38]. A longer follow-up duration and the assessment of time-dependent cumulative variables may be required to identify an association between metformin treatment and OS in diabetic lung cancer patients, especially for patients with early-stage disease. With regard to the relationship between dose-response and survival, Medairos et al. have demonstrated no evidence of a significant association between PFS and metformin use with increasing daily dosages [24]. Similar results have been reported in one colorectal cancer study [39]. To date, few studies have used dose-response variables for modeling metformin treatment; thus, further investigations are required to address this issue.

Cancer and diabetes are being diagnosed concurrently in individuals with increasing frequency 
[4]. Studies have revealed that the relationship between cancer and metformin treatment is complex and that factors affecting one or more parts of the cancer signaling network could be associated with cancer mortality. In laboratory studies, metformin has been shown to inhibit cell proliferation, reduce colony formation, and cause partial cell cycle interruption in several cancer cell lines [40-42]. These studies have suggested that metformin-induced activation of AMPK pathways may inhibit downstream cellular growth and proliferation in tumor cells, at least by inhibiting protein synthesis to some extent $[13,40]$. Metformin regulates the insulin level by ameliorating insulin sensitivity [1]. Additional in vivo studies have demonstrated that metformin exerts less anti-tumor activity in mice fed a control diet than in those fed a high-energy diet [43]. These findings suggest that the reduction in the endogenous insulin level by metformin may contribute to its anti-tumor activity [12]. Other in vitro studies have reported similar findings that metformin may kill cancer cells, reduce the cancer burden and enhance the effectiveness of breast cancer treatment [44-46]. Further, an observational study conducted by Jiralerspong et al. has reported increased pathologically complete responses of early-stage breast cancer patients undergoing neo-adjuvant therapy who had received metformin treatment compared with those who had received non-metformin treatment [47]. Based on the growing evidence of anti-cancer mechanisms of metformin reported in preclinical studies along with the results of retrospective analyses of the association between metformin and survival, metformin is considered a potential adjunctive cancer therapy [48].

Our meta-analysis has several limitations. First, the designs of the included retrospective studies differed, and the adjusted estimates used in these studies were not adjusted by the same variables. All of these factors could have caused heterogeneity among the studies. Although we applied a random-effects model that takes potential heterogeneity into consideration, careful interpretation of the heterogeneity is necessary. Second, the grouping of patients according to metformin/non-metformin treatment could be an oversimplified comparison. Most of the patients with lung cancer and diabetes received one or more glucose-lowering medications and other medications with dosage changes during the follow-up period. It is extremely difficult to evaluate the effects of intricate interactions among various medications on clinical outcomes.

\section{Conclusions}

In conclusion, our results provide an overview of recent evidence on the effects of metformin treatment in diabetic lung cancer patients, and they demonstrate a significant improvement in survival following metformin treatment. However, due to some limitations, our results should be interpreted cautiously. Further prospective, high-quality studies on the effects of metformin treatment in diabetic lung cancer patients must be conducted to confirm our findings.

\section{Abbreviations}

$\mathrm{HR}$, hazard ratio; 95\% $\mathrm{CI}, 95 \%$ confidence interval; OS, overall survival; PFS, progression-free survival; NSCLC, non-small cell lung cancer; SCLC, small cell lung cancer; TKI, tyrosine kinase inhibitor; PS, performance status; PET, positron emission tomography; NSE, neuronal specific enolase; LDH, lactate dehydrogenase; BMI, body mass index.

\section{Acknowledgements}

Our manuscript has been edited for proper English language, grammar, punctuation, spelling, and overall style at American Journal Experts (Certificate Verification Key: 5921-FB88-019F-3C8C-43C9).

\section{Authors' contributions}

Conception and design: XC, ZSW, and XW; Collection and assembly of data: All authors; Data analysis and interpretation: All authors; Manuscript writing: XC, ZSW, XDW, and XW; Final approval of manuscript: All authors.

\section{Competing Interests}

The authors have declared that no competing interest exists.

\section{References}

1. Gardner DG, Shoback DM, Greenspan FS. Greenspan's basic \& clinical endocrinology. In. McGraw-Hill Medical. 1999. http://www.columbia.edu/ cgi-bin/cul/resolve?clio10625507.

2. Richardson LC, Pollack LA. Therapy insight: Influence of type 2 diabetes on the development, treatment and outcomes of cancer. Nat Clin Pract Oncol. 2005; 2 : 48-53.

3. Dowling RJ, Niraula S, Stambolic V, et al. Metformin in cancer: translational challenges. J Mol Endocrinol. 2012; 48: R31-43.

4. Giovannucci E, Harlan DM, Archer MC, et al. Diabetes and cancer: a consensus report. CA Cancer J Clin. 2010; 60: 207-21.

5. Goodwin PJ, Ennis M, Pritchard KI, et al. Fasting insulin and outcome in early-stage breast cancer: results of a prospective cohort study. J Clin Oncol. 2002; 20: 42-51.

6. Pollak M. Insulin and insulin-like growth factor signalling in neoplasia. Nat Rev Cancer. 2008; 8: 915-28.

7. Stenvang J, Kumler I, Nygard SB, et al. Biomarker-guided repurposing of chemotherapeutic drugs for cancer therapy: a novel strategy in drug development. Front Oncol. 2013; 3: 313.

8. Medina-Franco JL, Giulianotti MA, Welmaker GS, et al. Shifting from the single to the multitarget paradigm in drug discovery. Drug Discov Today. 2013; 18: 495-501.

9. Gupta SC, Sung B, Prasad S, et al. Cancer drug discovery by repurposing: teaching new tricks to old dogs. Trends Pharmacol Sci. 2013; 34: 508-17.

10. Staels B. Metformin and pioglitazone: Effectively treating insulin resistance. Curr Med Res Opin. 2006; 22 Suppl 2: S27-37.

11. Committee CDACPGE. 2008 Clinical Practice Guidelines for the Prevention and Management of Diabetes in Canada. Can J Diabetes. 2008; 32: S1-201. 
12. Belfiore A, Frasca F, Pandini G, et al. Insulin receptor isoforms and insulin receptor/insulin-like growth factor receptor hybrids in physiology and disease. Endocr Rev. 2009; 30: 586-623.

13. Dowling RJ, Zakikhani M, Fantus IG, et al. Metformin inhibits mammalian target of rapamycin-dependent translation initiation in breast cancer cells. Cancer Res. 2007; 67: 10804-12.

14. Algire C, Moiseeva O, Deschenes-Simard X, et al. Metformin reduces endogenous reactive oxygen species and associated DNA damage. Cancer Prev Res. 2012; 5: 536-43.

15. Siegel RL, Miller KD, Jemal A. Cancer statistics, 2016. CA Cancer J Clin. 2016; 66: 7-30.

16. Rami-Porta R, Bolejack V, Crowley J, et al. The IASLC Lung Cancer Staging Project: Proposals for the Revisions of the T Descriptors in the Forthcoming Eighth Edition of the TNM Classification for Lung Cancer. J Thorac Oncol. 2015; 10: 990-1003.

17. Lin JJ, Gallagher EJ, Sigel K, et al. Survival of patients with stage IV lung cancer with diabetes treated with metformin. Am J Respir Crit Care Med. 2015; 191: 448-54.

18. Chen $\mathrm{H}, \mathrm{Yao} \mathrm{W}, \mathrm{Chu} \mathrm{Q}$, et al. Synergistic effects of metformin in combination with EGFR-TKI in the treatment of patients with advanced non-small cell lung cancer and type 2 diabetes. Cancer Lett. 2015; 369: 97-102.

19. Kong F, Gao F, Liu H, et al. Metformin use improves the survival of diabetic combined small-cell lung cancer patients. Tumour Biol. 2015; 36: 8101-6.

20. Xu T, Liang G, Yang L, et al. Prognosis of small cell lung cancer patients with diabetes treated with metformin. Clin Transl Oncol. 2015; 17: 819-24.

21. $\mathrm{Xu} \mathrm{H}$, Aldrich $\mathrm{MC}$, Chen $\mathrm{Q}$, et al. Validating drug repurposing signals using electronic health records: a case study of metformin associated with reduced cancer mortality. J Am Med Inform Assoc. 2015; 22: 179-91.

22. Arrieta O, Varela-Santoyo E, Soto-Perez-de-Celis E, et al. Metformin use and its effect on survival in diabetic patients with advanced non-small cell lung cancer. BMC cancer. 2016; 16: 633.

23. Lin J, Gill A, Zahm S, et al. Metformin Use and Survival after Non-Small Cell Lung Cancer: A Cohort Study in the U.S. Military Health System. International Journal of Cancer. 2017; [Epub ahead of print].

24. Medairos RA, Clark J, Holoubek S, et al. Metformin exposure is associated with improved progression-free survival in diabetic patients after resection for early-stage non-small cell lung cancer. J Thorac Cardiovasc Surg. 2016; 152: 55-61.

25. Wink KC, Belderbos JS, Dieleman EM, et al. Improved progression free survival for patients with diabetes and locally advanced non-small cell lung cancer (NSCLC) using metformin during concurrent chemoradiotherapy. Radiother Oncol. 2016; 118: 453-9.

26. Mazzone PJ, Rai H, Beukemann $\mathrm{M}$, et al. The effect of metformin and thiazolidinedione use on lung cancer in diabetics. BMC Cancer. 2012; 12: 410

27. [No authors listed]. Systemic treatment of early breast cancer by hormonal, cytotoxic, or immune therapy. 133 randomised trials involving 31,000 recurrences and 24,000 deaths among 75,000 women. Early Breast Cancer Trialists' Collaborative Group. Lancet. 1992; 339: 1-15.

28. Higgins JP, Thompson SG. Quantifying heterogeneity in a meta-analysis. Stat Med. 2002; 21: 1539-58

29. DerSimonian R, Laird N. Meta-analysis in clinical trials. Control Clin Trials. 1986; $7: 177-88$.

30. Sayed R, Saad AS, El Wakeel L, et al. Metformin Addition to Chemotherapy in Stage IV Non-Small Cell Lung Cancer: an Open Label Randomized Controlled Study. Asian Pac J Cancer Prev. 2015; 16: 6621-6.

31. Menamin UC, Cardwell CR, Hughes CM, et al. Metformin use and survival from lung cancer: A population-based cohort study. Lung Cancer. 2016; 94 : 35-9.

32. Tan BX, Yao WX, Ge J, et al. Prognostic influence of metformin as first-line chemotherapy for advanced nonsmall cell lung cancer in patients with type 2 diabetes. Cancer. 2011; 117: 5103-11.

33. Ahmed I, Ferro A, Cohler A, et al. Impact of metformin use on survival in locally-advanced, inoperable non-small cell lung cancer treated with definitive chemoradiation. J Thorac Dis. 2015; 7: 346-55.

34. Currie CJ, Poole CD, Jenkins-Jones $\mathrm{S}$, et al. Mortality after incident cancer in people with and without type 2 diabetes: impact of metformin on survival. Diabetes Care. 2012; 35: 299-304.

35. Suissa S. Immortal time bias in pharmaco-epidemiology. Am J Epidemiol. 2008; 167: 492-9.

36. Margel D, Urbach DR, Lipscombe LL, et al. Metformin use and all-cause and prostate cancer-specific mortality among men with diabetes. J Clin Oncol. 2013; 31: 3069-75.

37. Peeters PJ, Bazelier MT, Vestergaard P, et al. Use of metformin and survival of diabetic women with breast cancer. Curr Drug Saf. 2013; 8: 357-63.

38. Vissers PA, Cardwell CR, van de Poll-Franse LV, et al. The association between glucose-lowering drug use and mortality among breast cancer patients with type 2 diabetes. Breast Cancer Res Treat. 2015; 150: 427-37.

39. Mc Menamin UC, Murray LJ, Hughes CM, et al. Metformin use and survival after colorectal cancer: A population-based cohort study. Int J Cancer. 2016; 138: 369-79.

40. Zakikhani M, Dowling R, Fantus IG, et al. Metformin is an AMP kinase-dependent growth inhibitor for breast cancer cells. Cancer Res. 2006; 66: 10269-73.
41. Alimova IN, Liu B, Fan Z, et al. Metformin inhibits breast cancer cell growth, colony formation and induces cell cycle arrest in vitro. Cell Cycle. 2009; 8: 909-15.

42. Liu B, Fan Z, Edgerton SM, et al. Metformin induces unique biological and molecular responses in triple negative breast cancer cells. Cell Cycle. 2009; 8: 2031-40.

43. Algire C, Zakikhani M, Blouin MJ, et al. Metformin attenuates the stimulatory effect of a high-energy diet on in vivo LLC1 carcinoma growth. Endocr Relat Cancer. 2008; 15: 833-9.

44. Vazquez-Martin A, Oliveras-Ferraros C, Menendez JA. The antidiabetic drug metformin suppresses HER2 (erbB-2) oncoprotein overexpression via inhibition of the mTOR effector p70S6K1 in human breast carcinoma cells. Cell Cycle. 2009; 8: 88-96.

45. Hirsch HA, Iliopoulos D, Tsichlis PN, et al. Metformin selectively targets cancer stem cells, and acts together with chemotherapy to block tumor growth and prolong remission. Cancer Res. 2009; 69: 7507-11.

46. Oliveras-Ferraros C, Vazquez-Martin A, Menendez JA. Genome-wide inhibitory impact of the AMPK activator metformin on [kinesins, tubulins, histones, auroras and polo-like kinases] M-phase cell cycle genes in human breast cancer cells. Cell Cycle. 2009; 8: 1633-6.

47. Jiralerspong S, Palla SL, Giordano SH, et al. Metformin and pathologic complete responses to neoadjuvant chemotherapy in diabetic patients with breast cancer. J Clin Oncol. 2009; 27: 3297-302.

48. Pollak M. Overcoming Drug Development Bottlenecks With Repurposing: Repurposing biguanides to target energy metabolism for cancer treatment. Nat Med. 2014; 20: 591-3 